\title{
The Sacred in Cuba, Haiti, Brazil and Benin Republic: Aspects of a Linguistic and Cultural Dialogue
}

\author{
Hippolyte Brice Sogbossi (iD http://orcid.org/0000-0003-3047-244X \\ Departamento de Ciências Sociais e \\ Programa de Pós-Graduação em Antropologia \\ Universidade Federal de Sergipe \\ bricesogbo@hotmail.com
}

\begin{abstract}
The so-called Transatlantic Traffic imposed new linguistical and cultural configurations on the three continents involved in this tragedy: Africa, America and Europe. Such configurations acquire a complex of dynamics that, nowadays, we speak of flux and reflux of traffic, because of the intense and broad cultural and social exchange between these continents. Religion is one of the main or fundamental elements that is diluted in the cultural exchanges between Africa and America, especially those of the so called Sudanese nations, which receive various denominations: Santeria, Vodun, and Candomblé, among others. I will deal with the presentation of the jeje-nagô pattern in order to promote a dialogue, taking in account manifestation in Cuba, Haiti, Brazil and Benin. I will choose, describe and analyse from a comparative perspective a sample of songs and ritual lexicon (including terms of kinship) of Dahomean and Ewé-Fon origin in Arará Santeria, Vodun in Haiti, and Mina-Jeje Candomblé in Brazil in one part of the study, and in the other part, with the Vodun of Benin. This experience will undoubtedly shed light on the diversity and richness of meanings attributed from cultural and social relations in religious spaces and in society as a whole.
\end{abstract}

Keywords: Santeria, Candomblé, Vodun, songs, lexicon

Słowa kluczowe: santeria, candomblé, voodoo, pieśni, leksykon

In the anthropology of religion, more specifically of the Afro-American (or African American) religions, that I prefer to call the religions of African presence (I prefer this term as an alternative for the term "origin," very used) in the Americas, there are recurrent restless discussions and attempts at theoretical formulations on such 
a thought-provoking topic. The results of documental research and of that in the field are becoming more and more relevant, in such a way that new formulations require proof. When I go back to examine the religious realities in my fieldwork in Cuba (1991-1996), in the present-day Republic of Benin (since 1996), and in Brazil (1997 and 2018), I appreciate all the richness of information in more than 27 years on the legacy of Dahomean culture in the Americas and the multicultural dialogue between Africa and America. My goal is to select criteriously some central themes of the comprehension of the cultural dialogue among Brazil, Cuba, Haiti and Benin, always considering as a basis the Adja-Fon and Yoruba-Nago knowledge in the present day Republic of Benin. What are these themes? In understanding the dialogue, does it mean that it is limited to the commercial and transatlantic slave trade aspect and to the supposed redefinition of identities from the returnees, the former slaves and their descendants that go back to Africa? Which are the basic fundamentals that allow me to question this kind of dialogue? In the cultural aspect, does it mean that ritual language constitutes a sufficient element to explain this dialogue, or are there other elements that reinforce significations to the point of nullifying the first element, or simply make it indispensable? As for anonymous Afro-American literature, what are the challenges for its conservation and how are social conscience forms expressed in this treasure? What are the mechanisms of continuity in this process of preservation of the legacy?

Such a work is justified by the scarcity of research carried out on these themes. If work on one of the two sides of the Atlantic had been done, the necessary link between both sides could be a subject of research, but so far, very limited written works exist. Otherwise, it is necessary to investigate not only the cultural dialogue between Africa and America, but also the cultural dialogue among American countries as a whole, united and diverse on one side, and the African continent. In the eighteenth century, commercial relations between the two continents were intense, and they have continued developing in some way up until today. Considering all these aspects, my work can be based on, if necessary, conjectures that deal with the history of religious systems formation, and on possible origins of ethnic groups (which has been largely discussed by authors, who sometimes do convince, but sometimes do not); I must also discuss (or speculate) on the historical ground of intercultural dialogue between Africa and America, on the social, historical and cultural motivations of the dialogue, and on situations, occurrences and important and concrete processes of African heritage in the countries on this side of the Atlantic.

More recently, the relation between art and religion has been discussed, an undoubtedly legitimate concern, preoccupation that will progressively reinforce the importance of religious language in constant transformations, and of African presence and inspiration in the Americas. It is a relevant and timely theme. As far as art is concerned, there are a lot of manifestations: artefacts of African deities have great importance today. I think that, due to their importance, another moment must be reserved for their study. 


\section{Dahomean or Ewé-Fon elements in Arará Santeria, Vodun in Haiti, and Mina-Jeje Candomblé in Brazil}

The African presence in the New World has been identified throughout the Americas, from Canada to Patagonia. A brief reference to African enslavement between the fifteenth and nineteenth centuries shows how transatlantic trade has been the principal cause of the link between the countries or nations involved in the greatest holocaust that humanity has ever suffered. Triangular commerce may be considered as a consequence. I must note that other countries such as Haiti, the United States, Colombia, the Guayanas and Venezuela received African contingents.

As transatlantic commerce is concerned, the African imported nations were: Congo, Angola, Jeje, Maxi, Yoruba, Nagô, Fanti, Ashanti, Soninké, Pepel, Susu, Balanta, Malinké, Gangá, Peul, Bariba, Ibadan, Bambara, Wolof, Ewé, Mina, Arará, Malagashi, Abakuá, Carabali, Mossi, and others. On the composition of the religious nations, the studies of Fernando Ortiz, ${ }^{1}$ Bastide $^{2}$ and Métraux ${ }^{3}$ refer to the presence of:

Santería, in Cuba: Arará, of Dahomean origin, with reference to the present-day Republic of Benin; mainly from the group called Ewé-Fon, now Adja-Fon; Lucumí, with a major contingent of Yoruba and Nago, peoples localized in Benin, Togo and Nigeria; Congo, whose principal components are groups from the Bantu area, among them the Kikongo, Umbundo, Shona, and Lingala. Vodun, in Oriente and Camagüey: referring to the Haitian migrants from the end of the nineteenth century, after the Haitian Revolution.

Secret societies: Abakuá, or Ñáñigos. They proceeded from the margins of the Cross River at the frontier between Nigeria and Cameroon.

My experience with the Arará in Cuba, especially among residents of Jovellanos, Perico and Agramonte, lasted approximately 5 years.

Page 86 of my book: mi nyavalu o bisese... (Appendix 2)

Page 87 of my book: o bererê oberere... (Appendix 3)

Page 88 of my book: e na da gbe e de e à. (Appendix 4)

Vodun, in Haiti: integrated by various nations: Guedé (Gédévi), Aradás, Congo and Zandor (secret society). It is worth mentioning the importance of créole language, as an element of integration, with a substratum in French and Fon: see my article on the Fon presence in the créole of Haiti. Example: Lègba louvri barryè agooo eee. I identify words in the Fon language such as Lègba, name of a deity: the one who is a kind of trickster, who opens and locks the door; ago 'permission.' Louvri and barryè are créole forms of transcription for the French words ouvrir 'open' and barrière 'barrier.' The word vodun is mentioned only to show that religions of African presence are

\footnotetext{
${ }^{1}$ F. Ortiz, Glosario de afronegrismos, La Habana 1924.

${ }^{2}$ R. Bastide, Les Amériques Noires. Les civilisations africaines dans le Nouveau Monde, Paris 1967.

3 A. Metraux, Vodú, Buenos Aires 1963.
} 
diverse and are designated differently. For instance, Candomblé, Tambor de Mina, Batuque and so on in Brazil, are regional modalities of African presence cults in different regions of that country.

My objective here is to point out some of the characteristics of the African legacy in the Americas and to study the religious and cultural question. In other terms, I will discuss the flux, and take into account aspects like religious rituals, cosmology, parenthood and songs, and ritual languages. A basic premise of the studies on the dialogue between Africa and the Americas is provided by José Antonio Saco, a Cuban intellectual, when he quotes that we cannot think about the Americas without thinking about Africa, and vice versa. Thus, the study may start from the flux and the reflux, words created at that time by Pierre Verger to characterize both directions of the cultural heritage between the two continents. My use of the word "identity" refers to both similar and different cultural aspects among the three countries. It is worth mentioning that religion and language are of importance in these comparisons.

When I revise the concepts of ethnic groups and nations, I notice that ethnic groups can be considered countries, when I consider the period before the Berlin Conference in 1885. In the Benin Republic, for instance, Fon, Maxi, Yoruba, Dendi, Bariba, Mina $\mathrm{Ou}$ Gen, and others were countries. The concept of nation was reduced to a stable linguistic and cultural unit, established in a territory. After the Berlin Conference, the signification of the concept has changed, because of the new configuration of the continent by colonizers such as France, Spain, Portugal, England and Germany: the arbitrary division of Africa, which provoked confusion in the relations between nations and ethnic groups.

The situation persists to this day. Some tensions created from that violent destruction of the hegemony of realms and empires originated from the policy of divide to better rule. The process of colonization of the continent was a concrete practice of that policy. Settlement and exploitation colonies have been created. A lot of natural resources have been moved from Africa. Movements against colonization have been organized, and this contributed to the independence of many countries in the twentieth century. Pan-Africanism also helped in these victories. Pan-Africanism is the movement or link that united Africans from the continent and Africans of the diaspora with a common objective: complete liberation of the African continent. Movements of returnees (to the continent) were also organized.

\section{The study of linguistic retentions: Challenges and results}

\subsection{Cuba}

I am dealing with a remarkable presence that manifests itself in a corpus of ritual songs, lexicon, refrains and knowledge.

Phonetical level: koklo ('the cock') > kokoro.

I derive: koklosi from koklo 'the cock' and $s i$ 'wife.' It means 'the hen.' 
Koklozin: from koklo 'the cock' and azin 'the egg.' It means: 'the egg of a hen.' We know that the cock cannot lay eggs, only the hen.

Avun 'dog.'

Agbo 'goat, sheep.' In Fon it means 'kid.'

Yevojè 'sugar.'

Hrikè (in Cuba as well as in Brazil) 'knife.'

A sample of ritual songs. (See the appendixes).

Page 85 of my book on the Ewé-Fon in Cuba: Iye ya ma la die ee / osoji so ma na ci a / ejiso ma na ti a / nude ma do fie...

As for Cuba, some information was obtained from the communities of Jovellanos, Perico and Agramonte. I was able to know the level of comprehension of the contents of ritual songs. The question was to know whether the groups were conscious of what the messages in the lyrics were. I do not want to comment on a series of underlying behaviours related to secrets, because of the diversity of forms of replies from the informants. Some of them are reticent in furnishing the correct information. Some others do not know the real significance of the ritual songs, and argue that the deity is the only one that knows the content of the song, and so on. A fundamental element in the development of the present study has been fieldwork based on the work of informants from Jovellanos (Maximiliano Baró and Miguelina Baró) and from Perico (Emiliano Zulueta).

The samples - more than 180 ritual songs and prayers, 300 words and a highly significant number of proverbs, fables, guiles and refrains - are in Fon, except for cases of lexical loans of other African languages. It is important to draw attention to the fact that chants, prayers and lexicons are used according to their place, meaning that there are songs, prayers and ritual lexicon far from the ritual context as well.

There are some doubts on who was the soloist: if it was the deities, the drum players, or the interpreters of songs embedded in the public in general. The response is different in each context, and it depends on the importance of the secret. It seems that the content or meaning of the song is not the most important. And this is true with Afro-Brazilian adepts of Candomblé as well. What is of interest is the intention and the context in which the songs are performed.

The lexicon has been amplified to some 300 words and expressions of Dahomean origin in Cuba. Also, the universe of the ritual songs has been extended considerably. I studied phrases, refrains and knowledge of Adja-Fon origin, elements that have been registered in the linguistic and cultural treasure of the Ararás in Cuba. (The dog has four paws, but walks in one direction; the little pig asks his mother: "Why do you have such a big snout?" Etiological tales: the tortoise has been punished with a house that he carries all the time...). 


\subsection{Haiti}

Vodun in Haiti is integration of various nations: Guedé (Gédévi), Aradás, Congo and Zandor (secret society $\left.{ }^{4}\right)$. It is worth mentioning the importance of the créole language as an integration language, with a substratum in French and Fon. Example: Lègba louvri barryè agooo eee. We identify words in the Fon language such as Lègba, the name of a deity; ago 'license, permission.' Louvri and barryè, are forms of transcription to Créole the French words ouvrir 'to open' and barrière 'a barrier.' The word vodun has been used only to state that religions of African origin are diverse in the Americas.

The basis of the work is a sample of lexicon, knowledge and songs that I selected from various books and reviews. Le Vodu haïtien by Alfred Métraux (Buenos Aires, 1963), Le Royaume d'Ardra e son évangélisation au XVIIè siècle by Henri Labouret; Laennec Hurbon's Dieu dans le vodou haïtien (1987) and Guérin Montilus' Dieux en Diaspora: les loa haïtiens et les vaudou du Royaume d'Allada (Bénin) (Benin 1988).

The Fon presence - or another African language - in the Créole must be seen, not only in the words of African languages and in the texture of créole phrases, as quoted by Price-Mars, but also in the pronountiation and intonation of the lingua franca of enslaved Africans: the French language. In other words, we must see the presence in terms of influence.

\subsubsection{Pronounciation and intonation}

I distinguish three characteristics: stretching or great vowel shift; nasalization or shift from oralization to nasalisation; and nasalização or great nasal vowel shift

$\begin{array}{lll}\text { Stretching: }[\mathrm{er}]<[\varepsilon: \varepsilon] & \text { (According to Spanish phonetics). } \\ \text { French } & \text { Créole } & \text { English } \\ \text { servi } & \text { sèvi } & \text { 'served' } \\ \text { cher } & \text { chè } & \text { 'dear' } \\ \text { terre } & \text { tè } & \text { 'earth' }\end{array}$

Nasalization

[or] $<$ [õ]

French

Créole

English

mort

mon

'death'

$[\mathrm{e}]<[\tilde{\mathrm{e}}]$

French

Créole

English

Guinée

Guinen

'Guinea'

In the case of proper nouns such as René, Sénégal and Dahomey, Fon people pronounce them as: Hlenen, Senenga, and Danxomen, respectively.

${ }^{4}$ N. Lumarque, La religión vodu y uma experiencia danzaria: Doréus, Conferencia ofrecida em El III Seminario sobre Cultura afro-americana, La Habana, 23 de agosto de 1995. 


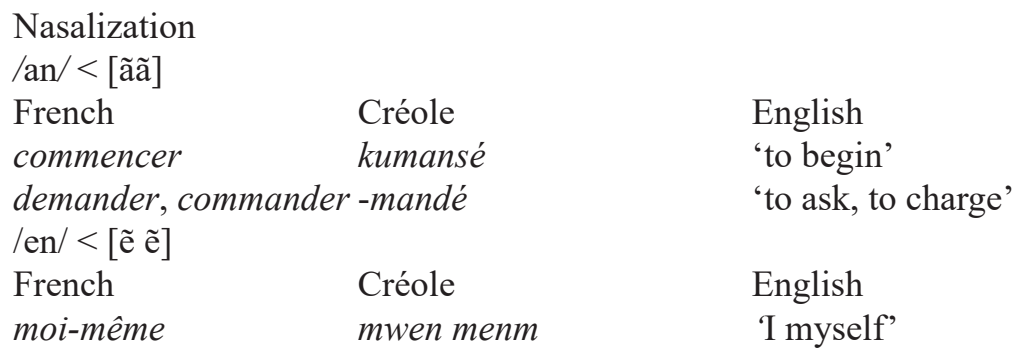

\subsubsection{Other linguistic transformations}

Phonetical aspects and phonological ones: nu; n'I; 'for' .

Morphological aspects: three cases of Fon presence: the morpheme of future $\{$ n'a $\}$; that of participle $\{$-eté $\}$ and those of infinitive $\{$-re $\}$ and $\{-e ́\}$.

Future: $\{n ' a\}$.

Jacques Roumain ${ }^{5}$ uses expressions such as n'a rivé..., n'a entré..., n'a remercié... All of them translated as 'we will come,' 'we will enter,' and 'we will acknowledge,' respectfully. In Fon the morpheme $\{n$ 'a\} is used for the future.

Participle: \{-eté\}

$\begin{array}{lll}\text { French } & \text { Créole } & \text { English } \\ \text { mettre (mis) } & \text { met (meté) } & \text { 'to put, put' }\end{array}$

In present-day Benin, among the Fon speakers of the coast, there is a tendency to use expressions or words from European languages such as French, English, or Portuguese, which demonstrates a similitude of this practice as compared with the Créole spoken in Haiti. This is also applicable to the infinitive.

Infinitive: apocope of the morpheme $\{-$ re $\}$

$\begin{array}{lll}\text { French } & \text { Créole } & \text { English } \\ \text { dire } & d i & \text { 'to say' } \\ \text { disparaître } & \text { disparêt } & \text { 'to disappear' }\end{array}$

Infinitive $\{$-é\}: used to express an action which occurs in the present or in the imperative

$\begin{array}{lll}\text { French } & \text { Créole } & \text { English } \\ \text { soulever } & \text { sulvé } & \text { 'to rise' } \\ \text { gronder } & \text { grondé } & \text { 'to curse, to huff' } \\ \text { éclairer } & \text { kleré } & \text { 'to illuminate' } \\ \text { jeter } & \text { jeété } & \text { 'to throw away' }\end{array}$

I do not consider the morphemes $\{$-té $\}$ and $\{n ' a\}$, referring respectively to the past and the future, that accompany these infinitives.

\footnotetext{
5 J. Roumain, Gouverneurs de la Rosée, Paris 1944, p. 69.
} 


\subsubsection{Lexical transformations}

Far from the compared lexicon of Fon terms in Haitian Vodun from the Dahomean and Haitian contexts, with words such as govi 'pitcher,' zen, 'pitcher' (also), hunsi 'adept of Vodun,' hunguenikon (hunjenukon) 'assistant of a priest of Vodun,' Ezili (Azili) 'the deity of sensuality, a kind of Ochun;' bokor (bokono) 'ifa priest,' hunfor (hunxo) 'the Vodun temple,' and so on...; Lègba (deity, equivalent to Exu of the Yoruba), hunguenikon (variant of hunjenukön 'assistant of a religious leader'), azaka (deity of Savalu people), hun (deity), and hungan (Vodun priest), I will only mention three words of Fon origin:

a) $M$ : personal pronoun. First singular person; it seems that it originates from $m$ or $u n$, from the Fon language. In this language it is used as a subject. In complementary form we use $m i$. According to Vaval, ${ }^{6} \mathrm{~m}$ is the contraction of $m w e n$ in Créole and both forms are used without distinction.

b) Ni: appears in Brown ${ }^{7}$ and means 'to him, to her,'

thus: $M(n)$ di ni: 'I tell him.' In Portuguese: 'I tell for him' (literally). To express "for him, for her," we use the form $n u I$, or the agglutinated form $n$ ' $i i$ or $n w i$. On Martinica Island $n u$ is used to refer the prepositions "to" and "for," as in Fon; in Haiti, $p u$ is used. The following example illustrates it well:

Zuk la sé sel medikaman nu ni

[Zuk this is medicine unique for me]

[Zuk is my only medicine]

c) Article $a$ is feminine "the." It is a definite article that is postponed in Créole language, exactly like in Fon and Yoruba.

ti fi a

[Small girl the]: 'the small girl'

Its origin seems to be from the Ewé or the Mina language. The definite article is $a$ or la in Ewé and in Mina.

\section{Syntactic aspects}

The analysis proves the similarity in the sequence of the words in Créole and in Fon. From the following example in Gouverneurs de la Rosée of Jacques Roumain, I give the Fon version, the syntactic structure and the translation in English.

Lègba, louvri baryè pu nu; ago yé.

'Lègba, open the door for me; license.'

Bef san ké, bon dye pusé much pu li.

'To the ox that has no tail, it is the good god that frightens the flies for him.'

${ }^{6}$ J.M. Vaval, Post-Graduate Student in the University of Havana, Informal interview on dahomean retentions in Haitian Culture. Havana, June 1995. Recorded in the Residence of Students (in my archives).

${ }^{7}$ O.C.Brown Jr., Haitian Vodou in relation to Négritude and Christianity a Study of Acculturation and Applied Anthropology, Indiana University, Ph.D dissertation. Ann Arbor, MI 1973. 
The phrase structure of Haitian Créole is very close to that of African languages such as Yoruba and Fon.

Semantics

Only one créole proverb is sufficient to prove the presence of Fon in Haitian thought:

Béfsan ké.

Bon dyé pusé much pu li.

'To the ox that has not tail.'

'The good god scares flies.'

In Benin, the Fon proverb to say the same thing is:

Kanlin e ma do si e.

Sé (gbé, mawu) wéno nya sukp n(u)i.

According to Guérin Montilus, ${ }^{8}$ the Fon influence is very clear in this theology of God that is fundamental for Haitian: God is the protector of the innocents, the orphans, the abandoned, and the chased. In Cuba also, a proverb with the same meaning still exists, with a mixture of Fon and the Spanish spoken by blacks in earlier times.

The presence of Fon and its similar forms in Haitian Créole is evident in pronounciation, intonation, and contexture, and its words and expressions.

In the case of Brazilian Portuguese, one of the research ${ }^{9}$ proves that there is an indisputable presence of the structure and signification of African languages such as Yoruba and Fon.

\subsection{Brazil}

In this country, research in São Luiz do Maranhão revealed:

- a resemblance to the tune:

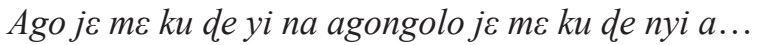

Tön si gbe we mi no do eee Gbe le un dooo.

- repetition almost faithful of the words:

Kpala mi ma yi tö xwe...

The adopted technique is direct and participant observation; I have been noting some data to more easily describe rituals. The funeral ritual must have importance and is described as taking into account principally two cult-houses: the Axé Opô Afonjá and the Bogum cult-houses. The Axexê in the first one has been dedicated to the Brazilian writer Jorge Amado, who died in August 2001. In the second one I participated in the seventh anniversary of the death of the mother-of-saint Evangelista dos Anjos Costa, doné Gamo Lokossi, also known as Nicinha. The zenli ceremonies included some Fon ritual songs such as the following:

${ }^{8}$ G. Montilus, Dieux en Diaspora: les loa haïtiens et les vaudou du Royaume d'Allada (Bénin), Benin 1988.

9 Y.P. de Castro, Falares africanos no Brasil, Rio de Janeiro 2002. 
Song

E ma ya vi ooo eee

Ee ma ya vi ooo

Avi ô nude we ko no gbo â

Zenli xô to ma damlon

Ton tô ma damlon

Hen nu wê eee

Amonlon de wê un nô ba aye
Free translation

Do not cry

Do not cry

Tears do not cure anything

The drummer of Zenli does not sleep

The drummer does not sleep

It is something of our customs

I am seeking sleep

With the objective of extending the field of comparison and to better understand funerary rituals, I had an opportunity to assist one Axexê in the Gantois cult house. It is certainly remarkable that the jeje-nagô houses of Bahia have a cultural dialogue; it means that, according to Nina Rodrigues, ${ }^{10}$ the two cults coexist so that we can speak more about a jeje-nagô mythology than a simple jeje or a nagô mythology. The cult houses of Roça do Ventura and of Hunkpamè Ayönu Huntölöji, both in Cachoeira, also have a series of rites performed such as the zandrö, a kind of night watch, the Azili ritual, and the tomar grá, a phase of a devotee initiation. There is also the Boitá ritual, the itá, some kinds of procession around sacred trees and to revered deities of the jeje pantheon.

\section{Conclusions}

Cultural and linguistic retentions in the New World recall Africa. The corpus of songs, words and expressions of African origin, specifically of Dahomean origin, phonetical, phonological and morphological aspects stand as sufficient evidence of this dialogue. The songs are occasionally translated literally in order to provide a total comprehension of the message from the poem or text. There are partial translations that need, to be more intelligible, an approximation between researcher and informant. The researcher needs to understand some keywords stored in the informant's memory, contextualize them, and then infer a major comprehension, a more complete comprehension. The legacy concerns various aspects such as art, religion, cooking, kinship, and others.

In short, this modest work, which does not assume to exhaust the topic nor to reach results and definitive conclusions, should be seen as a first approximation, and it will serve as an introduction to further research, or simply as an expansion of the studies that work on African retentions in general, and Dahomean in particular, in Latin American cultures.

The following appendixes are from my book on the Ewé-Fon in Cuba.

${ }^{10}$ N. Rodrigues, Os africanos no Brasil, Rio de Janeiro 1977. 


\section{Appendix 1}

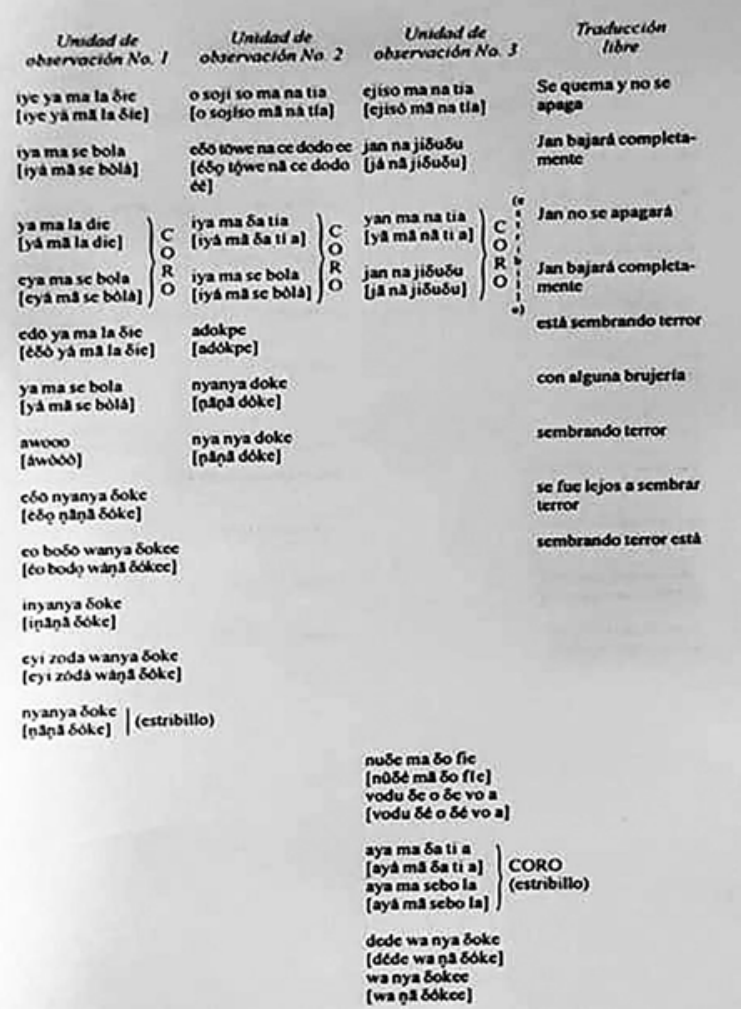

Free translation: He burns himself and does not extinguish / Jan (a pseudonym for Changó or Xèviosso) will descend fully / Jan will not be extinguished / Jan will descend fully / he is sowing confusion / With some deity sowing confusion/ he went far from us to sow confusion / sowing confusion is he.

Commentary: A common and coherent explanation in the observation units reveals that we were worshiping Xèviosso, called Sojiso (Changó in Yoruba), in order to descend and judge the criminal, the one that offends. 


\section{Appendix 2}

Unidad de observación No. I

\section{Versidnaraed}

Mi nyavalu obiscse [mi otvallo oblsese]

obo c\$o xoyeme\&e

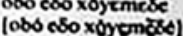

mi nyavalu obiscse [mi navalo oblsese]

obo eso xoyemese [ObO $450 \times 0$ yom 25 ]

mi nya valu [ml osvaló)

atinkpan nu [atikpa nu]]

\section{Lankpan 050 xojemese} [kalpa 050 xersose]

mi nyaralu nu biscse [mi pavalo no blsesc]

obisese hwe nyavalo [obisese hug navaló]

mi nyavalu o biscse [mi navalù obtsese]
Traduceion lisre

Alebamos a todas

las brujertas en la casa-templo

Alabamos a todas

las brujerlas en la casa-templo

Alabamos

a lodolo

que se encuentra en clla

Alabamos a todas

a todas alabató

Nlabamos a todas

Free translation: we praise all / the deities that are inside the terreiro / we praise all / the deities in the terreiro / we praise all the things that are inside the terreiro / we praise all of them / to all of them praise you / we praise all of them...

Commentary: The demonstration or evidence of a literal translation, word for word, of the content of the text, and resemblance in the version in the three observation units: it is reverence for the dead, for the divinized beings. 


\section{Appendix 3}

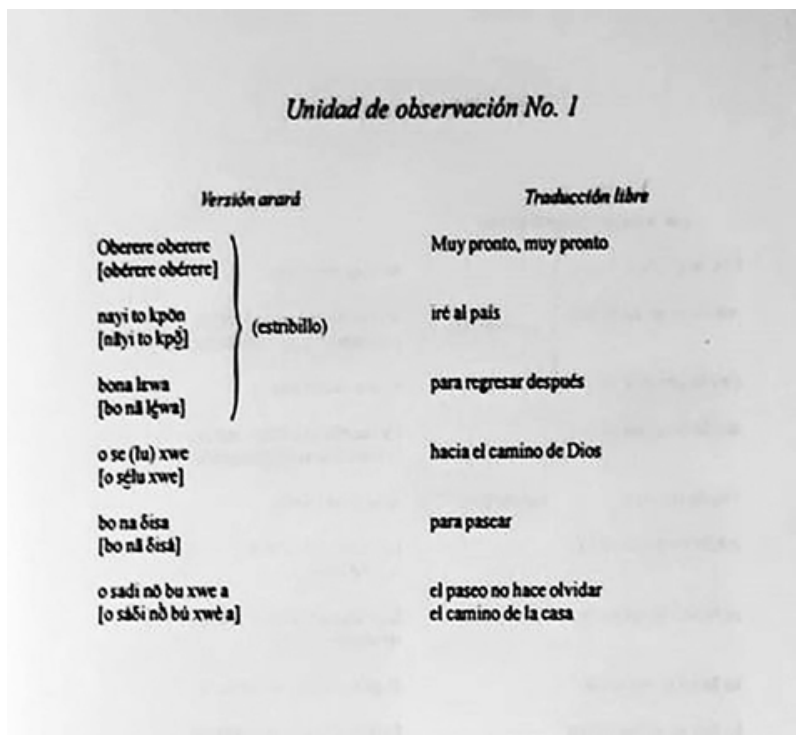

Free translation: As soon as, as soon as / I will travel to a country / to return afterwards / In the way of god, to walk / The journey does not have you forget the way to return home.

Commentary: It is clear that in the mind of the descendants of Dahomeans, that the physical return or the spiritual one is a certainty. Including in delegations from both Brazil and Cuba who went to the Ouidah 92 festival, and when the song was performed, all the Beninese people and "brothers and sisters of the diaspora" danced closely. 


\section{Appendix 4}

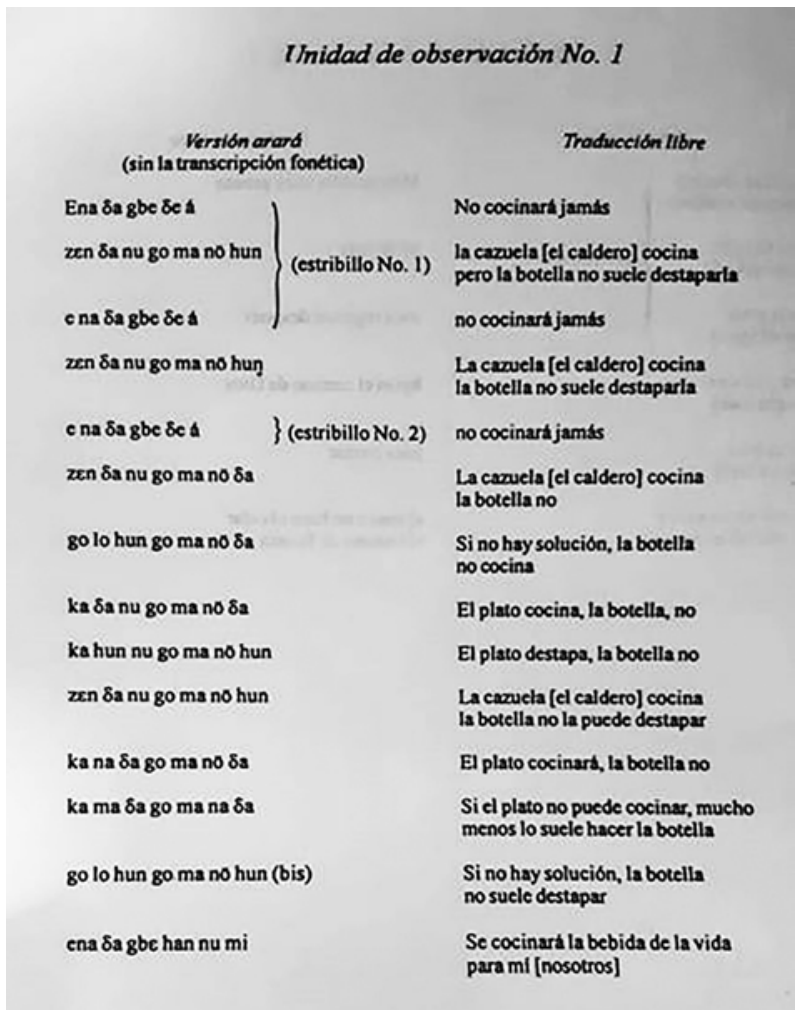

Free translation: Never will he cook. The pan cooks; the bottle no / If there is no solution, the bottle does not cook / The dish cooks, the bottle no / The dish opens; the bottle no / The pan cooks; the bottle cannot open it / The dish will cooks, the bottle no / If the dish cannot cook, much less is used to do the bottle / If there were no solution, the bottle is not used to open / The drink of life will be cooked for me.

Commentary: Maximiliano Baró, a Cuban Arará informant, told me that everything has its significance, and that everything serves something specific. True. This is the knowledge we should learn from this prayer. 


\section{References}

Aquino P. de., La mort défaite. Rites funéraires du candomblé, "L'Homme" 1998, no. 147, pp. 81-104.

Bastide R., Les Amériques Noires. Les civilisations africaines dans le Nouveau Monde, Paris 1967.

Brown O.C. Jr., Haitian Vodou in relation to Négritude and Christianity a Study of Acculturation and Applied Anthropology, Indiana University, Ph.D dissertation. Ann Arbor, MI 1973.

Castro Y.P. de, Falares africanos no Brasil, Rio de Janeiro 2002.

Hurbon L., Dieu dans Le Vodou Haïtien, H. Deschamps (ed.), Port-au-Prince 1987.

Lumarque N., La religión vodu y uma experiencia danzaria: Doréus, Conferencia ofrecida em El III Seminario sobre Cultura afro-americana, La Habana, 23 de agosto de 1995.

Metraux A., Vodú, Buenos Aires 1963.

Montilus G., Dieux en Diaspora: les loa haïtiens et les vaudou du Royaume d'Allada (Bénin), Benin 1988.

Ortiz F., Glosario de afronegrismos, La Habana 1924.

Price-Mars J., Asi habló el tío, La Habana 1968.

Rodrigues N., Os africanos no Brasil, Rio de Janeiro 1977.

Roumain J., Gouverneurs de la Rosée, Paris 1944.

Sogbossi H.B., Contribuição ao estudo da cosmologia e do ritual entre os Jeje no Brasil: Bahia e Maranhão, Rio de Janeiro 2004.

Sogbossi H.B., Introducción a la presencia fon en el créole hablado en Haití, "Oralidad" 1996, no. 8 , pp. 66-69.

Sogbossi H.B., La tradición ewé-fon en Cuba, La Habana 1998.

Sogbossi H.B., Morte e Parentesco na Bahia em Perspectiva Comparada: O Bogum e o Axé Opô Afonja, Work presented in the Work Group number 23 "New comparative models: Researches on afro-indigenous collectives," in the 35th Annual Encounter of ANPOCS. Caxambu, MG, October $24^{\text {th }}-28^{\text {th }}, 2011$.

Sogbossi H.B., Morte e Religião na Bahia: um estudo de ritual e simbolismos, [in:] Estudos sobre Religião, C.C. Bezerra (ed.), Aracaju 2009, pp. 301-322.

Sogbossi H.B., Remanentes lingüísticos Adja-fon en léxico y cantos rituales localizados en dos municipios del occidente cubano, "Anales del Caribe" 1995, no. 14-15, pp. 201-206.

Vaval J.M., Post-Graduate Student in the University of Havana, Informal interview on dahomean retentions in Haitian Culture, Havana, June 1995. Recorded in the Residence of Students (in my archives).

Verger P., Flux et Reflux de la Traite des Nègres entre Le Golfe de Guinée et la Baie de Tous les Saints au Brésil Salvador, Bahia 1977.

\section{Films and documentaries:}

Atlântico Negro, R. Barbieri (dir.), prod. Videografia, Iser 1998, https://www.youtube.com/ watch? $=\mathrm{zDj} 0 \mathrm{TVjAJsI}$ (access: 24.10.2016).

Pedra da Memória, R. Amaral (dir.), prod. Maracá Cultura Brasileira, São Paulo 2012, https:// vimeo.com/56037980 (access: 24.10.2016). 